\title{
Effects of goat browsing on gambel oak communities in northern Utah
}

ROBERT A. RIGGS AND PHILIP J. URNESS

\section{Abstract}

Replicated populations of 5 shrub species were monitored over a 3-year period to assess community responses to intensive browsing by Spanish-type goats. Response variables included stem density, stem-size distribution skewness, stem diameter-stem production relations, and sprout abundance and weight. No species exhibited a density change. Size distribution skewness increased only in browsed oak (Quercus gambelit Nutt.) populations. Sprout weights also increased in browsed oak populations, but declined in comparably browsed serviceberry (A melanchier alnifolia Nutt.) populations. The only other significant sprouting response was an increase in sprout numbers in browsed snowberry (Symphoricarpos oreophilus Gray) populations. Relationships between basal stem diameter and stem production of 4 species were altered by goat use. The slopes of these relations were consistently lower in browsed populations of oak and serviceberry than in adjacent control populations, indicating that browsing reduced productivity, especially of large stems. Conversely, slopes of rabbitbrush (Chrysothamnus viscidtflorus lanceolatus (Hook.) Nutt.) relations increased in goat-browsed pastures relative to those of control populations; rabbitbrush was avoided by goats. Similarly, big sagebrush (Artemisia tridentata wyomingensis Nutt.) was avoided and its stem production responded positively in communities subjected to goat browsing. Important cumulative effects of goat browsing included declines in productivity of serviceberry and oak, and an increase in that of sagebrush.

Key Words: browsing responses, stem density, size distribution skewness, sprouting response, stem-size-production relations

Control of Gambel oak on rangelands has been a long-standing interest of range managers. Improvements in cattle carrying capacity, livestock dispersal and handling, and soil moisture retention have been attributed to oak control (Marquiss 1972, Tew 1969). Not surprisingly, most research on this topic has been motivated by a desire to enhance livestock production via increases in herbaceous production that typically accompany oak control. Yet big game wintering on oakbrush ranges may benefit as well because oak control typically retards successional advance and increases browse availability (Kufeld 1977, 1983).

Gambel oak is deciduous and its apparent winter-time nutritive value is low compared to that of associated shrubs (Welch et al. 1983), especially nondeciduous species such as sagebrush (Kufeld et al. 1981). Yet Gambel oak is less susceptible to traditional shrub control techniques (i.e., fire, herbicides, mechanical control) than associated species (Kufeld 1983). Thus while traditional shrubcontrol methods can improve browse availability, they may also lower the nutritive value of the browse base by shifting species

\footnotetext{
At the time of this research, Riggs was research assistant and Urness was associate professor, Range Science Department, Utah State University, Logan 84322. Riggs is currently wildlife biologist, Boise Cascade Corporation, Timber and and Wood Products Group, Northeast Oregon Region, P.O. Box 610, LaGrande, Ore. 97850.

Research was funded by the Utah Division of Wildlife Resources (Federal aid project W-105-R) and the Utah Agricultural Experiment Station; it is published as

Journal Paper 3527, Utah Agricultural Experiment Station, Utah State University, Logan 84322.

We thank D. Sisson and D. Turner, Department of Applied Statistics, Utah State University, for assistance with experimental design and analysis. We also thank $F$.

Provenza and B. Dick for critical reviews of the manuscript.

Manuscript accepted 9 March 1989.
}

composition toward oak. Consequently, identification of management strategies capable of selective oak reduction is desirable. Selective control might also enhance herbaceous species, thereby serving both wildlife and livestock interests.

Controlled browsing by domestic goats may be a viable management alternative. Angora and milk-type goats have been used to control Gambel oak sprouts following mechanical treatment (Davis et al. 1975). More recently, Spanish goats have been shown to have greater potential for shrub control than either sheep or Angora goats (Warren et al. 1984), and to have dietary habits suited to selective control of Gambel oak under certain management constraints (Riggs et al. 1988). However, data concerning the effects of goats on entire oakbrush communities is lacking, despite the obvious implications that it might have for management of livestock and game range alike. In this paper we report the effects of summer-time goat use on a typical oakbrush winter range community in northern Utah.

\section{Study Area}

The study site is near the town of Henefer, at the interface between Wasatch chaparral and sagebrush-grass zones (Cronquist et al. 1972). Average annual precipitation and temperature are 350 $\mathrm{mm}$ and $7.1^{\circ} \mathrm{C}$, respectively. The experiment was conducted in a typical low-elevation oakbrush community, occurring on a deep, loamy alluvial deposit. Elevation was $1,860 \mathrm{~m}$. Slope was $13 \%$ and azimuth was $295^{\circ} \mathrm{N}$. Oak stems ranged in height from a few centimeters to slightly over $2 \mathrm{~m}$ and the relative abundance of tall stems graded slightly from one end of the site to the other.

\section{Methods}

\section{Treatment and Response Variables}

Responses to goat browsing were investigated in 6 experimental oakbrush communities that were created by subdividing a naturally occurring parent community into smaller units. The parent community was first divided into three, 0.4 ha blocks, and each block was then subdivided into two, 0.2 -ha pastures. One pasture in each block was subsequently stocked during the growing season with Spanish-type goat wethers while the other was maintained as a control pasture. Responses of each shrub species and of the herbaceous strata were then monitored annually in each of the 6 experimental units.

Stocked pastures each received, 1,340 goat-days per hectare in 1984, and 1,840 goat-days in 1985; they were rested in 1986. The treatment pastures were stocked with goats in a series of highintensity, short-duration periods designed to maximize defoliation of Gambel oak. Additional information regarding the study site, stocking strategy, and dietary habits of the goats has been published elsewhere (Riggs et al. 1988).

The first response variable was the density of live, rooted shrub stems. Density was estimated for each shrub species during late June of each year. Stems were counted in 10 permanent $5-\mathrm{m}^{2}$ macroplots (Oldemeyer and Regelin 1980) in each pasture, and the data were compared by analysis of variance (ANOVA).

The second response variable was the stem-size distribution of live 
stems. The standardized skewness coefficient $\left(g_{1}\right)$ was used to gauge shifts in these distributions. Size was calibrated each year, in terms of the cross-sectional basal diameter $(\mathrm{mm})$, on 200 randomly selected stems in each population (Cole 1963). A standardized skewness coefficient was then calculated for each sample distribution, and the collection of coefficients was compared across treatments and years by ANOVA.

The third response variable was the relationship between stem size and stem production (i.e., size-specific production); this was estimated annually for non-sprouts in each experimental population using a size-stratified, random sample of 50 rooted stems. Size was calibrated in terms of cross-sectional basal diameter (mm). Stem productivity (g/stem) was calculated as the product of each stem's leader count and average leader weight ([stem production] = [mean twig weight] $\times$ [twig count]). Leader weights were predicted for a systematic subsample of leaders on each sample stem using twig-diameter-weight regressions. Parameters of the relationship (i.e., slope and intercept) were analyzed in sequence for treatment effects by an analysis of covariance in which the concomitant variable was basal diameter and the dependent variable was stem production. An intercept analysis was conducted only in the absence of significant slope differences. Both variables (basal diameter, production) were log-transformed to linearize the relationships for analysis.

Equations predicting size-specific stem production $(\mathrm{Pr})$ were generated for experimental populations according to results of the covariate analysis. Separate equations were generated according to treatment if the covariance analysis detected differences in either slope or intercept; pasture samples were pooled to generate a common equation in the absence of any differences. Equations were generated using the $\log$ model: $\ln (\mathrm{Pr})=\ln (\mathrm{b} \varphi)+\mathrm{bl}[\ln (\mathrm{D})]$; where Pr was production per stem (g/stem), D was basal stem diameter ( $\mathrm{mm})$, In was the natural $\log$ function, and $\mathrm{b} \varphi$ and $\mathrm{bl}$ were intercept and slope coefficients, respectively. For the sake of brevity, the antilog form of the equation, $\operatorname{Pr}=b \varphi(D)^{b 1}$, with the coefficient of determination $\left(r^{2}\right)$, is used in this paper.

In lieu of a covariate analysis, conditional tests for production homogeneity among populations were conducted for 4 of the 5 species (serviceberry, sagebrush, rabbitbrush, and snowberry) in 1984. Differences were not expected to occur during the first year, and an abbreviated analysis was considered adequate for detecting any initial differences that may have existed among the experimen- tal populations. The methodology involved sampling the productivity of a predominant size class of stems in each population (rather than the entire size range) and subjecting the data to a blocked ANOVA for treatment effects; production homogeneity among populations was assumed in the absence of a significant test. None of these tests yielded significant results, and initial homogeneity was assumed among the various populations of these species. Gambel oak, on the other hand, was subjected to covariate analysis in all 3 years because it was the community dominant and target of the treatment.

Sprouting responses (frequency and weight of sprouts in the production samples) were treated separately. Rooted sprouts were excluded from the covariate production analysis because their size-production relations were expected to differ from those of nonsprouts (Rumble 1987). Rooted sprouts are composed only of current annual growth (CAG) while non-sprouts of equal diameter are composed of both CAG and old growth; thus separate analyses are required.

Utilization estimates were obtained at the same time as the production estimates. Twig utilization was defined as the percentage of CAG removed and/or killed by browsing. Utilized weights were predicted with the same regressions used to predict twig weights.

Herbaceous composition was estimated by ocular appraisal of basal area coverage, in 2 permanent $5-\mathrm{dm}^{2}$ microplots nested in each macroplot. In addition, two $1-\mathrm{m}^{2}$ circular plots were nested in each macroplot and clipped to obtain production estimates in August, 1986.

Finally, we constructed a cumulative-effects model using data for all the various response variables. Output was productivity by species (kg/ha), generated using point estimates for density, size distributions, stem size-production relations, and sprout responses derived in the foregoing analyses. Productivity was calculated for each species, under each treatment, by: (1) weighting the density estimates by the proportion of stems in various size classes; (2) weighting the resulting histograms by the size-specific productivity predicted for stems at the midpoint of each size, after adjusting for the proportions of sprouts and non-sprouts in each class; and (3) summing these size-class values.

\section{Experimental Design}

A 2-factor, complete block design was used to analyze the data. Main effects were blocks, goat use (without respect to density) and

Table 1. Initial botanical compodition of experimental pastures, 1984.

\begin{tabular}{|c|c|c|c|c|c|c|c|}
\hline \multirow[b]{2}{*}{ Plant taxa } & \multicolumn{3}{|c|}{ Control pastures } & \multicolumn{3}{|c|}{ Stocked pastures } & \multirow[b]{2}{*}{ Mean \pm S.E. ${ }^{2}$} \\
\hline & Block \#1 & Block \#2 & Block \#3 & Block \#1 & Block \#2 & Block $\# 3$ & \\
\hline $\begin{array}{l}\text { Shrubs } \\
\text { Amelanchier alnifolia } \\
\text { Artemisia tridentata } \\
\text { Berberis repens } \\
\text { Chrysothamnus viscidiflorus } \\
\text { Purshia tridentata } \\
\text { Quercus gambelii } \\
\text { Rosa sp. } \\
\text { Symphoricarpos oreophilus }\end{array}$ & $\begin{array}{r}2.7 \\
3.5 \\
0.2 \\
23.3 \\
2.5 \\
36.7 \\
0.0 \\
4.6\end{array}$ & $\begin{array}{r}2.4 \\
10.6 \\
3.4 \\
18.6 \\
1.5 \\
1.5 \\
23.3 \\
0.0 \\
0.0 \\
36.5\end{array}$ & $\begin{array}{r}0.0 \\
2.0 \\
0.0 \\
32.7 \\
0.8 \\
27.8 \\
0.0 \\
19.9\end{array}$ & $\begin{array}{r}1.8 \\
5.2 \\
1.3 \\
17.9 \\
0.0 \\
18.9 \\
0.0 \\
25.5\end{array}$ & $\begin{array}{r}4.3 \\
0.8 \\
5.2 \\
13.0 \\
0.8 \\
0.8 \\
28.5 \\
0.0 \\
17.7\end{array}$ & $\begin{array}{r}1.0 \\
7.4 \\
5.0 \\
12.4 \\
1.9 \\
26.0 \\
1.2 \\
10.8\end{array}$ & $\begin{array}{r}2.0 \pm 0.6 \\
4.9 \pm 1.5 \\
2.5 \pm 1.0 \\
19.7 \pm 3.1 \\
1.3 \pm 0.4 \\
26.9 \pm 2.4 \\
0.2 \pm 0.2 \\
19.2 \pm 4.6\end{array}$ \\
\hline $\begin{array}{l}\text { Graminoids } \\
\text { Poa pratensis } \\
\text { other }^{3}\end{array}$ & $\begin{array}{l}8.8 \\
0.9\end{array}$ & $\begin{array}{l}7.7 \\
2.5\end{array}$ & $\begin{array}{r}16.4 \\
0.2\end{array}$ & $\begin{array}{r}16.0 \\
0.9\end{array}$ & $\begin{array}{r}12.1 \\
0.8\end{array}$ & $\begin{array}{r}11.5 \\
1.1\end{array}$ & $\begin{array}{r}12.1 \pm 1.5 \\
1.1 \pm 0.3\end{array}$ \\
\hline Forbs ${ }^{2}$ & 0.8 & 0.1 & 0.4 & 1.0 & 0.9 & 0.3 & $0.6 \pm 0.2$ \\
\hline
\end{tabular}

IShrub data are average, rooted-stem density per 5- $\mathrm{m}^{2}$ macroplot; grass and forb data are average basal area coverage (\%) per 10 -dm² microplot.

2Differences between controls and stocked pastures were not significant ( $\leq \leq 0.05$ ). Nomenclature follows Cronquist et al. (1972).

'Other graminoids were Agropyron smithii, Agropyron spicatum, Bromus teciorum, Carex geyeri, Stipa columbiana, Stipa comata, and Poa fendleriana. None of these accounted for $\geq 1 \%$ coverage in any pasture.

"Thirty-one forb species were recorded, but none averaged as much as $1 \%$ coverage. Species which composed as much as $1 \%$ coverage in at least one microplot included $A c h i l l e a$ millefolium, Antennaria microphylla, Aster integrifolius, Collinsia parviflora, Comandra umbellata, Erigeron pumilus, Gilia aggregata, Helianthella uniflora, and Lathyrus pauciflorus. 
years. Blocks were a random effect; both goat use and years were fixed. The year effect was a repeated measure. This design was used for ANOVA for stem density, stem-size distributions and sprout responses. Covariate ANOVA of size-specific stem productivity simply involved adding stem diameter to the design, as the concommitant. RUMMAGE software was used to analyze the data (Bryce 1980).

Block-randomization was used to distribute goats because we suspected that utilization might differ among pastures. We based this suspicion on the height gradient observed among oak stems; if goats were unable to reach the tallest stems, utilization of oak would vary along the height gradient. The pastures had to be randomized prior to any browsing and we elected to use the block design, rather than a completely randomized design, in order to account for a potentially height-related utilization differential. However, we observed during the browsing periods that goats defoliated all stems without regard to height; this resulted from their ability to assume a bipedal stance while feeding, which allowed them to "ride down" even the tallest stems. Therefore, the height gradient became biologically unimportant, and we view our initial block-randomization as unnecessarily restrictive (i.e., a completely randomized design would have been appropriate). We have adhered to the block-randomized design for this analysis, but caution the reader that it is likely conservative. Consequently, we have also reported some results that were visually obvious to us, but only marginally significant in the context of the blockrandomized analysis.

\section{Results}

\section{Utilization Levels}

Sagebrush, rabbitbrush, and snowberry were consumed little by goats (Riggs et al. 1988). Sagebrush utilization was only $2.4 \%$ (SE = 0.8 ) for both twig and leaf material, with no differences between years. Utilization of rabbitbrush was $2.7 \%$ ( $\mathrm{SE}=0.8$ ) and $3.4 \%$ (SE $=0.9$ ) for twigs and leaves, respectively, and no difference occurred between years. Utilization of snowberry twigs and leaves, however, varied between years $(P<0.03)$. Twig utilization increased from $0.8 \%$ (SE $=0.8$ ) in 1984 to $39.8 \%$ ( $\mathrm{SE}=0.1$ ) in 1985 ; likewise, leaf utilization increased from $1.4 \%(\mathrm{SE}=1.0)$ to $52.8 \%(\mathrm{SE}=0.2)$. The greater use of snowberry in 1985 apparently resulted from the greater number of animal-days applied to the stocked pastures that year.

Conversely, both serviceberry and Gambel oak were avidly consumed. Serviceberry browse was not abundant in the pastures and its utilization was high, despite a low occurrence in the diet (Riggs et al. 1988); utilization averaged $48.6 \%(\mathrm{SE}=3.4)$ and $53.3 \%(\mathrm{SE}=$ 3.3) of twigs and leaves, respectively, with no significant difference between years $(P>0.10)$. Utilization of oak fractions was lower $(P<0.05)$ in 1984 than 1985 . Twig utilization was $20.0 \%(\mathrm{SE}=0.3)$ in 1984 and $56.2 \%(\mathrm{SE}=0.3)$ in 1985 ; leaf utilization was $43.3 \%$ (SE $=8.1)$ and $64.3 \%(\mathrm{SE}=3.6)$ in 1984 and 1985 , respectively.

\section{Composition Responses}

Pasture composition did not differ in 1984 at the outset of the experiment (Table 1). No changes $(P \leq 0.10)$ were detected in the subsequent 2 years, either in the density of shrub stems or in the basal area coverage of herbaceous species.

\section{Dynamics of Stem-Size Distributions}

Minimum and maximum stem diameters were stable throughout the study in all populations, and skewness of size distributions shifted in only the browsed oak populations $(P<0.08$, Fig. 1). All oak distributions were positively skewed in 1984, indicating an initial abundance of small stems relative to large ones. Skewness of all the browsed populations increased as the experiment progressed while that of the control populations remained constant;

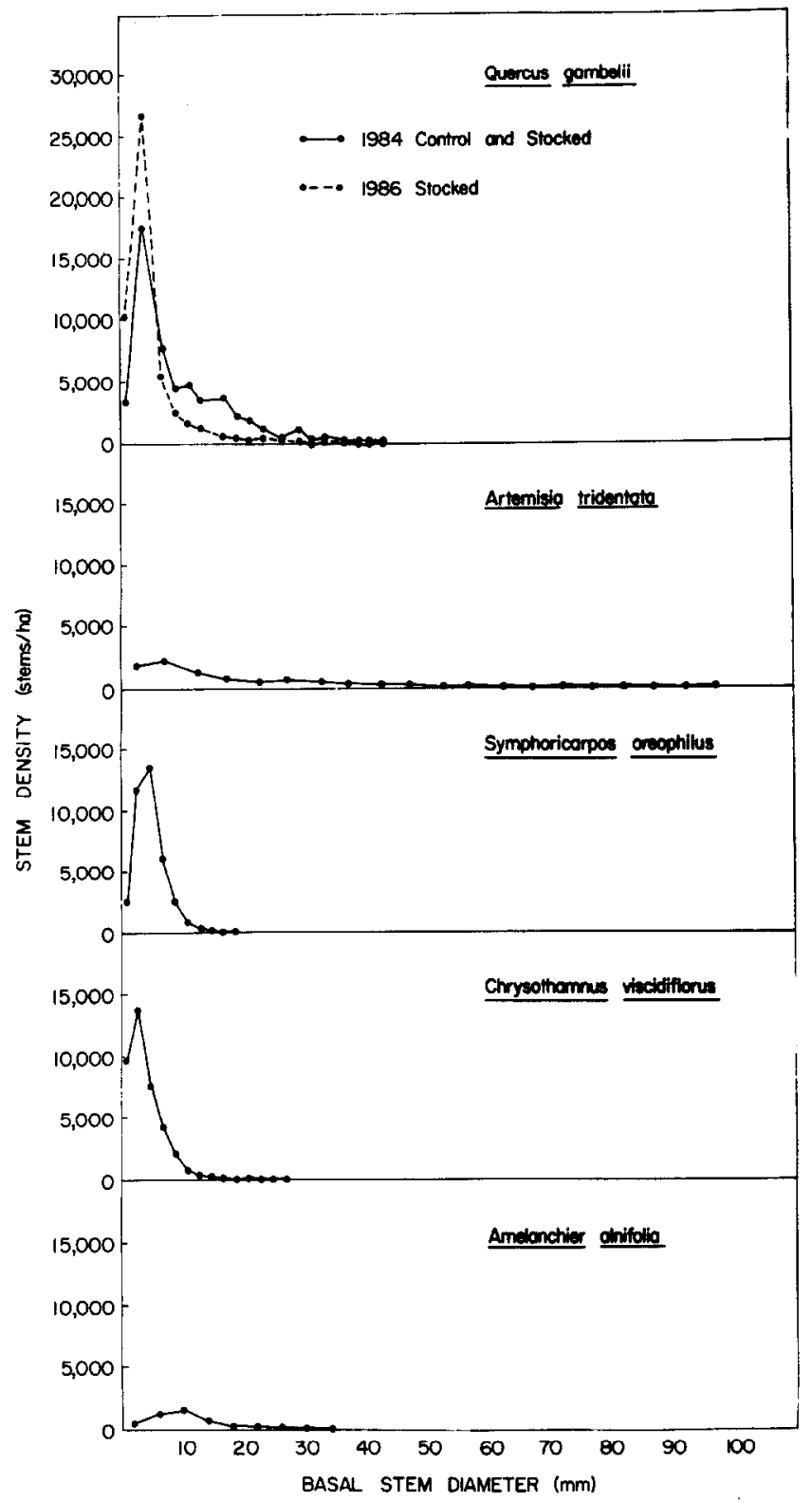

Fig. 1. Pooled sample distributions of stem size in 1984 and 1986. Only the size distribution of oak was affected by goats.

the treatment effect became significant in the third year (Fig. 2). This progressive skewing, at constant density, indicated that the relative abundance of smaller stems had increased in the population, and implied that both mortality of old stems and increased sprouting were involved. Both factors were visually obvious.

\section{Sprout Responses}

Browsing did not affect the sprouting rate of serviceberry populations. Sprouts composed $74 \%(\mathrm{SE}=5.6)$ of the rooted serviceberry stems less than $4 \mathrm{~mm}$ in diameter. This percentage did not differ among populations at any time during the 3-year period. However, sprout weights did differ between treatments $(P<0.09)$. Sprout dry-weights averaged $0.58 \mathrm{~g}$ among control populations versus $0.21 \mathrm{~g}$ among browsed populations $\left(\mathrm{LSD}_{.10}=0.25\right)$.

Rabbitbrush sprouting was apparently unaffected. Rabbitbrush sprout diameters did not reach $2 \mathrm{~mm}$ and sprouts comprised about $66.7 \%$ (SE = 9.6) of all the rooted stems that were smaller than this diameter, regardless of treatment or year. Rabbitbrush sprouts 


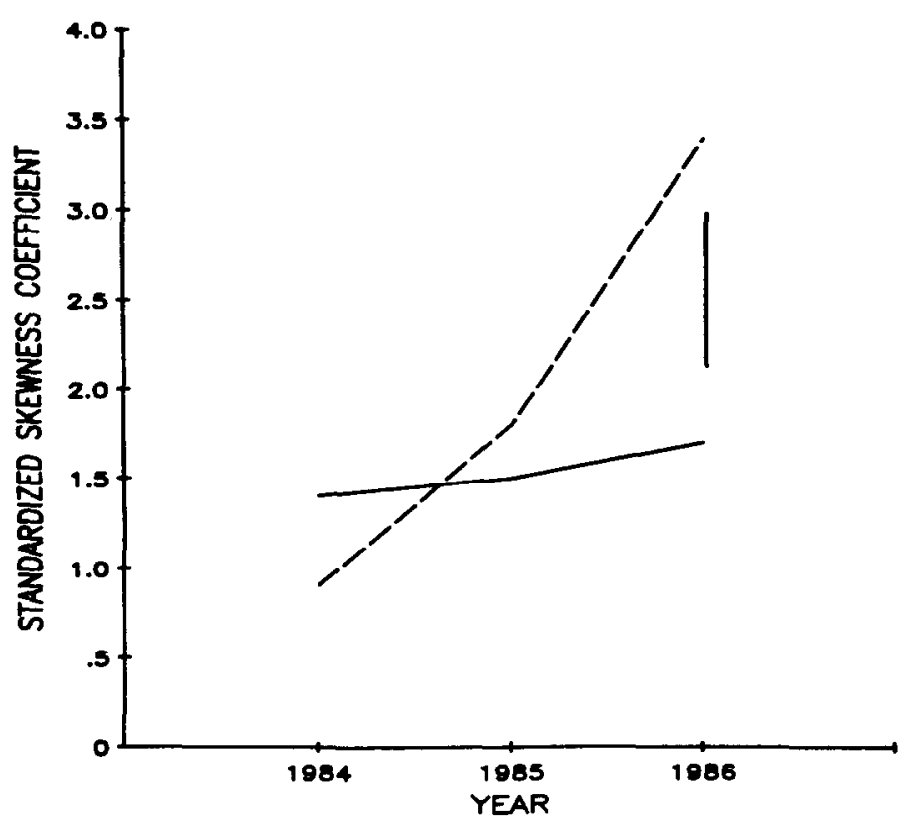

Fig. 2. Changes in the standardized skewness coefficient for sample basaldiameter distributions of rooted oak stems, 1984-86. The vertical bar corresponds to the LSD.10 between controls (solid line) and stocked pastures (dashed line) observed in 1986.

averaged $0.35 \mathrm{~g}(\mathrm{SE}=0.10)$.

The increased skewness of stem-size distributions seen in the browsed oak populations was partially due to increased sprouting. Oak sprouts did not exceed $10 \mathrm{~mm}$ in diameter, and the proportion of sprouts occurring in subsamples of stems under $10 \mathrm{~mm}$ diameter varied significantly $(P<0.03)$ by treatment and year. Sprout numbers increased in the stocked pastures but did not change in the controls (Fig. 3). Sprouts comprised $10.7 \%$ and $10.0 \%$ of all oak stems less than $10 \mathrm{~mm}$ diameter in 1984 and 1985 , respectively. In 1986, sprouts comprised $90.0 \%$ of the browsed-population sam-

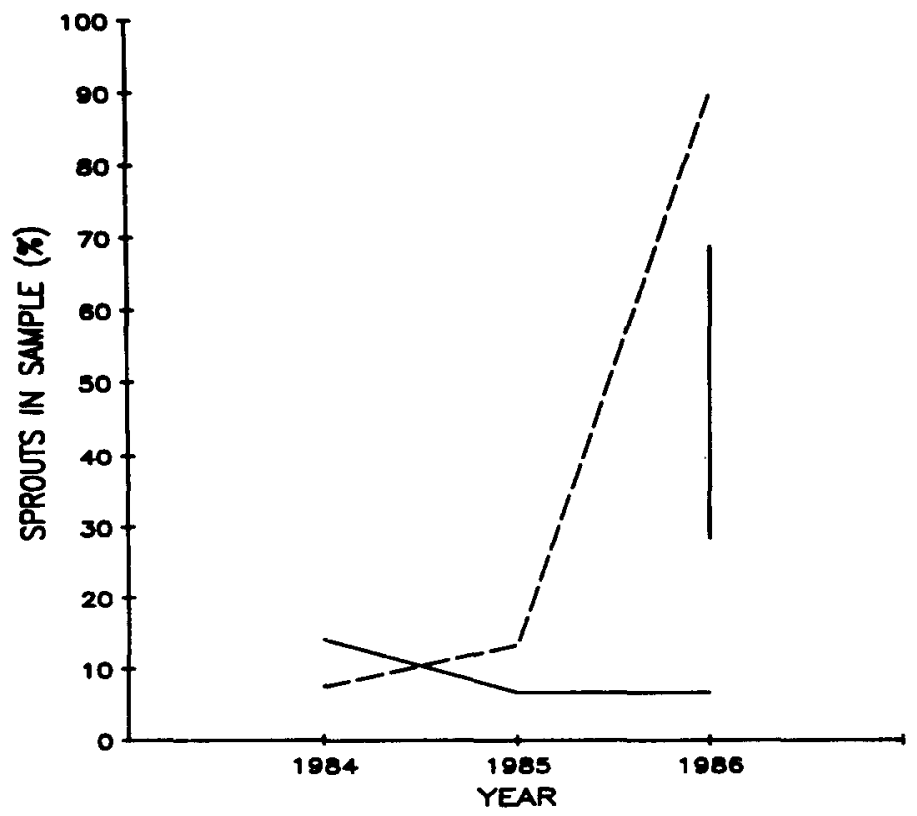

Fig. 3. Changes in the percentage of live, rooted, oak stems under $10 \mathrm{~mm}$ basal diameter that were sprouts, 1984-86. The vertical bar corresponds to the LSD.06 between controls (solid line) and stocked pastures (dashed line) observed in 1986. ples, but only $6.7 \%$ of the control samples. Browsing did not affect sprout weight in either 1984 or $1985(\bar{x}=1.26 \mathrm{~g} \mathrm{SE}=0.59)$, but a weight difference was observed in 1986 when sprouts averaged 2.90 $\mathrm{g}$ and $1.15 \mathrm{~g}$ in browsed and control populations, respectively $\left(\right.$ LSD $\left._{10}=0.81\right)$.

Snowberry did not exhibit a sprouting response. Basal diameter of snowberry sprouts seldom reach $4 \mathrm{~mm}(P=0.03)$, and browsing did not alter the frequency of sprouts under this size. However, the proportion of sprouts in the subsamples did vary between years with regard to treatment $(P<0.05)$. This proportion increased, in both browsed and control populations, from $31.7 \%$ in 1985 to $58.3 \%$ in 1986 (LSD $05=25.9$ ). Dry weight of snowberry sprouts was unaffected by either browsing or year; dry weights consistently averaged $0.52 \mathrm{~g}(\mathrm{SE}=0.06)$.

\section{Covariate Production Responses to Nonsprouts}

A highly significant $(P<0.0001)$ relationship was observed between basal diameter and productivity of rooted serviceberry stems. Browsing had a significant effect on the slope of the relationship $(P<0.03)$. Neither the main effect of year nor the treatment $\times$ year interaction was significant $(P>0.35)$, indicating that the magnitude of the effect did not change between 1985 and 1986. Slope of the relation for control stems $(\operatorname{Pr}=0.22(D))^{1.47}, r^{2}=0.70, n$ $=181)$ was more than twice that for browsed stems $\left(\operatorname{Pr}=0.28(D){ }^{0.63}\right.$, $\mathrm{r}^{2}=0.32, \mathrm{n}=157$ ) in both 1985 and 1986, indicating that the productivity of non-sprouts was reduced by browsing, especially that of larger stems. The relationship for browsed stems was weaker than that for controls.

Sagebrush also exhibited a highly significant $(P<0.0001)$ relationship between basal diameter and productivity, and slope heterogeneity was detected between treatments in an analysis of vegetative production $(P<0.13)$; as in the serviceberry analysis, neither the year effect nor the treatment $X$ year interaction was significant. The slope of the relationship for control stems $(\operatorname{Pr}=0.09(D))^{1.63}, r^{2}=$ $0.87, \mathrm{n}=291)$ was lower than that for stems in stocked pastures $(\mathrm{Pr}$ $=0.13(D)^{1.78}, \mathrm{r}^{2}=0.87, \mathrm{n}=292$ ); strength of the relationship was the same in both treatments. The difference in vigor of plants was clearly visible in the pastures. We concluded that avoidance of sagebrush by goats conferred a competitive advantage to this species, and magnitude of the production response increased with plant size.

We also estimated production of reproductive leaders $(\mathrm{RPr})$ by sagebrush plants, but only in 1986 . The size-production relation was highly significant $(P<0.0001)$, but weak $\left(\operatorname{RPr}=0.33(D)^{0.99}, \mathrm{r}^{2}=\right.$ $0.33, n=292$ ). No heterogeneity of slope or intercept was detected $(P>0.40)$. Therefore, any reproductive response that may have occurred did not appear to extend beyond the presence of goats in the pastures.

Rabbitbrush populations also exhibited a highly significant stem diameter-production relationship $(P<0.0001)$. There was no slope heterogeneity between treatments without respect to years $(P>0.35)$. However, there was significant heterogeneity between years without respect to treatment $(P<0.03)$; slope of the relationship declined significantly from 1985 to 1986 (Table 2 ). In addition, a treatment $X$ year interaction was indicated $(P<0.14)$. No slope differential was detected between treatments in 1985; in 1986, the control relationship had a lower slope than did the treatment relationship (Table 2). We concluded that a size-specific decline in stem productivity had occurred in both treatments, but the decline was less precipitous in the stocked pastures where goats had avoided this species during the previous 2 years. The difference was visually obvious in 1986.

Oak also exhibited a significant over-all relationship between stem diameter and stem production $(P<0.0001)$. Slope heterogeneity was detected between treatments without respect to years $(P<0.10)$, and among years without respect to treatment $(P<0.02)$. 
Table 2. Comparisons of stem diameter-production regression, $\mathbf{P}=$ b\%(D)b1, for rabbitbrush, 1985-86.

\begin{tabular}{|c|c|c|c|c|c|}
\hline Treatment & Year & $\mathrm{b} \emptyset$ & bl & $\begin{array}{l}\text { Adjusted } \\
\qquad \mathrm{r}^{2}\end{array}$ & $\mathrm{n}$ \\
\hline \multicolumn{6}{|c|}{ Treatment Comparisons (without respect to year) ${ }^{1}$} \\
\hline Controls & Both & 0.83 & 0.92 & 0.46 & 256 \\
\hline Stocked & Both & 0.74 & 1.05 & 0.46 & 259 \\
\hline \multicolumn{6}{|c|}{ Year Comparisons (without respect to treatment) ${ }^{2}$} \\
\hline Both & 1985 & 0.62 & $1.18 \mathrm{a}$ & 0.61 & 264 \\
\hline Both & 1986 & 0.94 & $0.82 \mathrm{~b}$ & 0.36 & 251 \\
\hline \multicolumn{6}{|c|}{ Treatment $\times$ Year Comparisons ${ }^{3}$} \\
\hline Controls & 1985 & 0.65 & $1.15 \mathrm{a}$ & 0.65 & 132 \\
\hline Stocked & 1985 & 0.57 & $1.23 \mathrm{a}$ & 0.54 & 132 \\
\hline Controls & 1986 & 1.01 & $0.71 \mathrm{~b}$ & 0.31 & 124 \\
\hline Stocked & 1986 & 0.88 & $0.92 \mathrm{c}$ & 0.42 & 127 \\
\hline
\end{tabular}

${ }^{1}$ Difference between slopes is not significant.

${ }^{2}$ Unlike letters denote a difference between slopes $(p \leq 0.02)$.

${ }^{3}$ Unlike letters denote differences among slopes $(p \leq 0.14)$.

However, the treatment $\times$ year interaction was not significant $(P=$ $0.254)$.

The treatment effect was obvious (Fig. 4). However, it was not visually apparent until 1985, suggesting that the interaction was a real phenomenon despite the low statistical significance. We felt

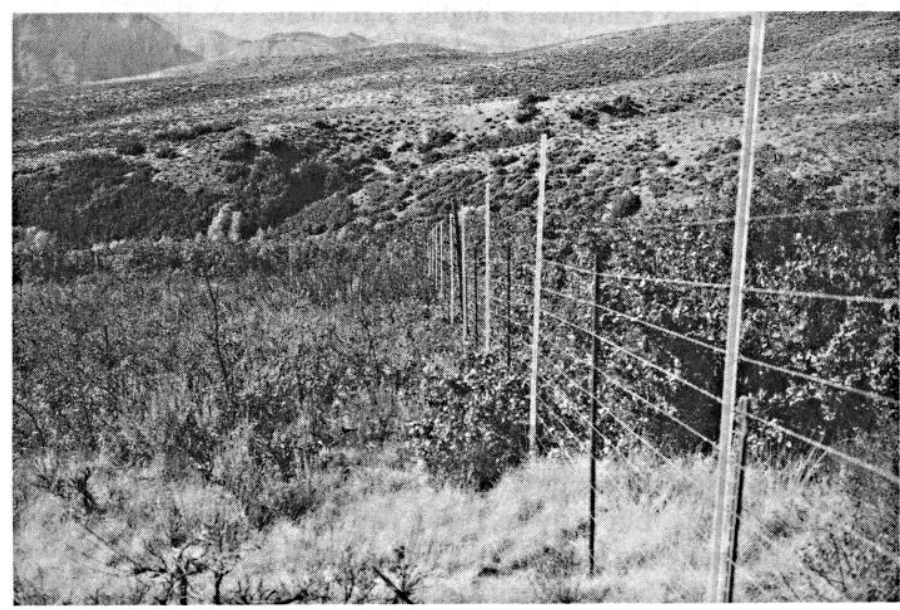

Fig. 4. Fence-line comparison illustrates the difference in productivity of browsed oak stems (left) and unbrowsed controls (right), 1986.

that the low significance might well have resulted from the conservative experimental design (which was unnecessarily restrictive). Consequently, Table 3 displays the regression coefficients at the interaction level, as well as at the level of the main effects. Comparison of the regression coefficients at the level of the main effects indicates that the browsing effect was consistent throughout the study, and that slopes dropped in 1985 (regardless of treatment), and then rebounded in 1986 (regardless of treatment). In contrast, comparison of the regression coefficients at the level of the interaction suggests that there was not a great disparity of regression coefficients between treatments until after 1984. The statistical analysis forces one to conclude that the first interpretation is the appropriate one. However, failure to detect the interaction simply may have resulted from the conservative, block-randomized analy$\operatorname{sis}^{1}$. Therefore, we caution against any expectation of depressing

${ }^{1}$ Reanalysis of the data in the context of a completely randomized design found the interaction effect to be significant $(P<0.05)$. However, there is no theoretical justification for conducting such an analysis (Anderson 1970).
Table 3. Comparisons of stem diameter-production regression, $\mathbf{P}=$ b甲(D)b1, for Gambel oak, 1984-86.

\begin{tabular}{|c|c|c|c|c|c|}
\hline Treatment & Year & $\mathrm{b} \emptyset$ & \multicolumn{3}{|c|}{ Adjusted } \\
\hline \multicolumn{6}{|c|}{ Treatment Comparisons (without respect to year) ${ }^{1}$} \\
\hline Controls & all & 0.25 & $1.64 \mathrm{a}$ & 0.78 & 424 \\
\hline Browsed & all & 1.32 & $0.64 \mathrm{~b}$ & 0.22 & 375 \\
\hline \multicolumn{6}{|c|}{ Year Comparisons (without respect to treatment) ${ }^{2}$} \\
\hline Both & 1984 & 0.40 & $1.41 \mathrm{a}$ & 0.77 & 272 \\
\hline Both & 1985 & 0.40 & $1.17 \mathrm{~b}$ & 0.40 & 283 \\
\hline Both & 1986 & 0.34 & $1.40 \mathrm{a}$ & 0.33 & 244 \\
\hline \multicolumn{6}{|c|}{ Treatment $\times$ Year Comparisons ${ }^{3}$} \\
\hline Controls & 1984 & 0.37 & 1.46 & 0.75 & 134 \\
\hline Controls & 1985 & 0.21 & 1.57 & 0.80 & 148 \\
\hline Controls & 1986 & 0.22 & 1.85 & 0.88 & 142 \\
\hline Browsed & 1984 & 0.43 & 1.36 & 0.81 & 138 \\
\hline Browsed & 1985 & 0.93 & 0.68 & 0.21 & 135 \\
\hline Browsed & 1986 & 0.69 & 0.76 & 0.21 & 102 \\
\hline
\end{tabular}

${ }^{1}$ Unlike letters indicate a difference between slopes $(p \leq 0.10)$.

${ }^{2}$ Unlike letters indicate differences among slopes $(p \leq 0.02)$.

${ }^{3}$ Slope differences are not statistically significant $(p>0.25)$ in a block-randomized analysis.

oak stems with only 1 season of browsing, even at the heavy stocking level we employed. In either case, timing of the browsing effect may be a trivial point from a practical perspective if one considers that imposing goat browsing for only one year seems unlikely in most operational settings. The important point is that repeated browsing will certainly reduce oak vigor.

Snowberry stems also exhibited a highly significant relationship between basal diameter and production $(P<0.0001)$, but neither of its parameters was affected by treatment, year, or their interaction $(P<0.35)$. Consequently, the data were pooled over treatments and years to generate a single regression $(\operatorname{Pr}=0.50(D))^{1.22}, r^{2}=0.54, n=$ $504)$. We concluded that productivity of non-sprouts was not affected to a significant extent by the browsing treatment or by differences in growing conditions between years.

\section{Cumulative Effects on Shrubs}

Reduced productivity of mature serviceberry stems, coupled with reduced sprout vigor, lowered productivity of browsed serviceberry populations. Productivity of model control population was $26 \mathrm{~kg}$ / ha versus $4 \mathrm{~kg}$ / ha for a browsed population (Fig. 5).

In the case of Gambel oak, all variables responded to the intense browsing, and the net effect was a severe $(78 \%)$ reduction in productivity of populations (Fig. 5). Model output for control populations was $754 \mathrm{~kg} / \mathrm{ha}$, with only $0.4 \%$ of this produced by sprouts. In sharp contrast, browsed populations produced only $166 \mathrm{~kg} / \mathrm{ha}$, and $61 \%$ of this was sprouts. This comparison was calculated using the main-effect differences in Table 3, rather than the interactionlevel differences; it may be conservative.

Sagebrush was the only shrub to show a strong positive response. Neither its density nor its size distribution was changed by goats, but the increase in stem production moved population productivity markedly upward. Model output for combined vegetative and reproductive production was $236 \mathrm{~kg} /$ ha under control conditions, versus $494 \mathrm{~kg} /$ ha with goats (Fig. 5). The difference between treatments was obvious.

Productivity of rabbitbrush and snowberry populations was not markedly affected. Rabbitbrush productivity was $132 \mathrm{~kg} / \mathrm{ha}$ in 1984. Neither the control nor the treatment values differed much in $1986(106 \mathrm{~kg} / \mathrm{ha}$ and $128 \mathrm{~kg} / \mathrm{ha}$, respectively). Model production for snowberry was $134 \mathrm{~kg} /$ ha in both treatments.

\section{Herbaceous Production}

Clipping data suggested that understory production increased in the stocked pastures, relative to the controls. However, statistical 


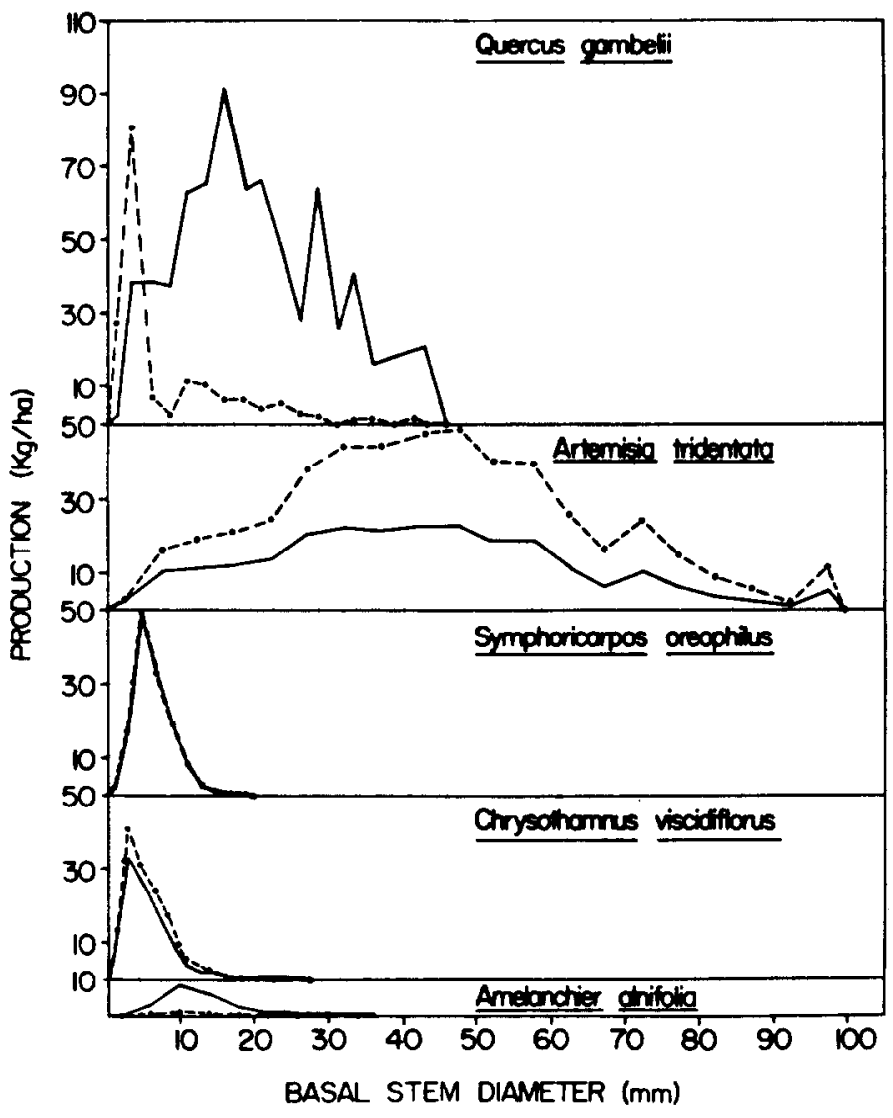

Fis. 5. Net effect of goats on productivity of shrub populations $(\mathrm{kg} / \mathrm{ha})$, 1986. Curves plot productivity of various size classes for control populations (solid lines) versus populations in goat-stocked pastures (broken lines). Areas underneath curves reflect productivity of model populations.

evidence was weak. In 1986, graminoid production averaged 420 $\mathrm{kg} / \mathrm{ha}(\mathrm{SE}=45)$ across control pastures, compared to $660 \mathrm{~kg} / \mathrm{ha}$ $(\mathrm{SE}=43)$ across stocked pastures, but the difference was not significant $(P<0.6)$. Likewise, forb production was only $90 \mathrm{~kg} / \mathrm{ha}$ $(\mathrm{SE}=8)$ across the controls versus $110 \mathrm{~kg} / \mathrm{ha}(\mathrm{SE}=8)$ across stocked pastures $(p>0.8)$. The pooled estimate for graminoids and forbs was $510 \mathrm{~kg} / \mathrm{ha}(\mathrm{SE}=49)$ and $780 \mathrm{~kg} / \mathrm{ha}(\mathrm{SE}=48)$ in controls and stocked pastures, respectively, with no significant difference.

Herbage density varies spatially in oakbrush because distribution of the various shrub species is clumped. Lack of statistical significance likely resulted from randomly locating the plots and the small number of plots ( $n=20$ per pasture). The treatment effect was significant when grass and forb data were pooled across pastures (i.e., $n=60$ plots per treatment without respect to block replication), and the means compared on the basis of the pooled variance $\left(\mathrm{LSD}_{0.05}=51\right)$. An increase in herbaceous production is expected following uniform shrub control in oakbrush communities (Marquiss 1972, Moinat 1956, Price 1938). Likewise, a positive herbaceous response should be expected following a partial shrub reduction, but its spatial variability should be greater than that following a uniform shrub removal. We concluded that herbage production had increased in the goat-browsed pastures. Increased sampling may have detected the treatment effect, but the sampling level required may have been prohibitive without prior stratification of plots according to shrub composition.

\section{Discussion}

Both serviceberry and Gambel oak were reduced by browsing in this experiment, and by utilization levels that were not as extreme as those required to harm these species in earlier clipping studies (Young and Payne 1948, Shepherd 1971). The apparently lower resilience to goat browsing might be attributed to a timing difference between ungulate browsing and artificial clipping. Clipping is generally imposed between mid-summer and early fall, after plants have been afforded some opportunity to store nutrients. In contrast, we initiated goat browsing in late spring and repeated it during the course of the growing season (Riggs et al. 1988); thus the opportunity to store nutrients may have been reduced, and resilience reduced accordingly (Engle et al. 1983). Stem damage also resulted from animals gnawing on bark below the point of current annual growth, and this probably lowered stem vigor as well.

Positive or neutral responses observed for sagebrush, green rabbitbrush, and snowberry contrasted sharply with the largely negative responses which Kufeld (1983) reported for these species following chaining, spraying or burning. However, minor components of the community that are palatable (e.g., serviceberry) may be negatively impacted. Results in other areas will be affected by stocking strategy, species composition, and relative palatability of community components.

Long-term effects are yet to be assessed, and rate of return to prebrowsed conditions will be of particular interest. The shortterm results presented here suggest increased herbaceous production for other livestock, and goat-induced changes in the browse base may well be beneficial to big game wintering on such communities. Sagebrush is higher in crude protein and dry matter digestibility, and lower in indigestible fiber, than associated deciduous species in winter (Kufeld et al. 1981, Welch 1983, Welch et al. 1983). Thus such treatment may benefit wintering ungulates, assuming that they would adjust their dietary behavior (botanical composition, dry matter intake) so as to take advantage of increased sagebrush availability.

Several response variables were monitored in this experiment, but these were not equally sensitive to goats. Stem density was insensitive in this study despite a rather intense sampling scheme. Similarly, skewness of stem-size distributions did not respond except in the case of oak, which was severely browsed. Stem diameter-production relationships were more sensitive than either density or size-distribution of populations in this experiment. Whether this holds in studies concerned with more moderate treatments and/or long-term successional dynamics remains to be seen.

Predictive power of the stem diameter-production relations, as reflected by $\mathrm{r}^{2}$ values, varied among species and may be expected to vary with treatment severity as well. The relationship was strong for species that had fairly wide ranges of basal stem diameter and stem production (e.g., sagebrush, serviceberry, and oak). In contrast, rabbitbrush and snowberry populations exhibited limited ranges for these variables, and weaker regression relationships. Little difference in precision was observed between control populations and those that were only moderately stressed or enhanced (e.g., rabbitbrush, snowberry, and sagebrush), but precision declined markedly if stem damage was severe (e.g., serviceberry and oak). High short-term variance may not persist over the long term, and it may not be expected to appear at all in long-term studies concerned with more subtle browsing treatments.

We employed the standardized skewness coefficient to detect size-distribution changes in this study, but it may not be an appropriate response variable in other situations. In this study, experimental populations were demarcated via subdivision of a single parent community. Neither minimum nor maximum stem sizes varied among pastures initially, and no changes in these parameters were detected during the course of the experiment. Therefore, the range and location of size distributions were con- 
stant, and only changes in shape of the distributions were a concern. Skewness is a shape statistic, but it is insensitive to differences in scale or location among distributions. Location differences, in particular, are apt to occur in field experiments that employ experimental designs based on site characteristics or stand history. For example, a shrub population on a ridge might have a very different stem-size range than another population in an adjacent swale. Likewise, shrub stands of different ages might be expected to have different size ranges. Also, locational shift may be more apt to develop in long-term experiments than in short-term studies like this one. Where locational shift does occur, the coefficient of variation, or the gini coefficient, may be more appropriate response variables than skewness (Bendel et al. 1989).

\section{Literature Cited}

Anderson, V.L. 1970. Restriction errors for linear models (an aid to develop models for designed experiments). Biometrics 26:255-268.

Bendel, R.B., S.S. Higgins, J.E. Teberg, and D.A. Pyke. 1989. Comparison of skewness coefficient, coefficient of variation, and gini coefficient as measures of inequality. Oecologia (Berlin). In Press.

Bryce, G.R. 1980. Data analysis in Rummage Il. Dep. Stat., Brigham Young Univ., Provo, Utah.

Cole, G. 1963. Range survey guide. Grand Teton Natur. Hist. Assoc., Moose, Wyo.

Cronquist, A., A.H. Holmgren, N.H. Holmgren, and J.L. Reveal. 1972. Intermount. Flora, Vol. 1. Hafner Publ, Co.

Davis, G.G., L.E. Bartel, and C.W. Cook. 1975. Control of Gambel oak sprouts by goats. J. Range Manage. 28:216-218.

Engle, D.M., C.D. Bonham, and L.E. Bartel. 1983. Ecological characteristics and control of Gambel oak. J. Range Manage. 36:363-365.

Kufeld, R.C. 1977. Improving Gambel oak ranges for elk and mule deer by spraying with 2,4,5-TP. J. Range Manage. 30:53-57.

Kufeld, R.C. 1983. Responses of elk, mule deer, cattle, and vegetation to burning, spraying, and chaining of Gambel oak rangeland. Colorado Div. Wildl. Tech. Pub. 34.
Kufeld, R.C., M. Stevens, and D.C. Bowden. 1981. Winter variation in nutrient and fiber content and in vitro digestibility of Gambel oak (Quercus gambelii) and big sagebrush (Artemisia tridentata) from diversified sites in Colorado. J. Range Manage. 34:149-151.

Marquiss, R.W. 1972. Soil moisture, forage, and beef production benefits from Gambel oak control in southwestern Colorado. J. Range Manage. 25:146-150.

Moinat, A.D. 1956. Comparative yields of herbage from oak scrub and interspersed grasslands in Colorado. Ecology 37:852-854.

Oldemeyer, J.L., and W.L. Regelin. 1980. Comparison of 9 methods for estimating density of shrubs and saplings in Alaska. J. Wildl. Manage. 44:662-666.

Price, R. 1938. Artificial reseeding on oak-brush ranges in central Utah. USDA Circ. 458.

Riggs, R.A., P.J. Urness, and T.A. Hall. 1988. Diets and weight gains of Spanish goats used to control Gambel oak. Small Ruminant Res. 1:259-271.

Rumble, M.A. 1987. Using twig diameters to estimate browse utilization on three shrub species in southeastern Montana. p. 172-175 In: Proc.Symp. on Plant-Herbivore Interactions. USDA Forest Serv. Gen. Tech. Rep. INT-222.

Shepherd, H.R. 1971. Effects of clipping on key browse species in southwestern Colorado. Colo. Div. Game, Fish and Parks Tech. Pub. 28.

Tew, R.K. 1969. Converting Gambel oak sites to grass reduces soilmoisture depletion. USDA Forest Serv. Res. Note INT-104.

Warren, L.E., D.N. Ueckert, and J.M. Shelton. 1984. Comparative diets of Rambouillet, Barbado, and Karakul sheep and Spanish and Angora goats. J. Range Manage. 37:172-180.

Welch, B.L. 1983. Big sagebrush: nutrition, selection, and controversey. p. 21-33. In: K.L. Johnson (ed.). Proc. First Utah Shrub Ecology Workshop. Utah State University, Logan.

Welch, B.L., S.B. Monsen, and N.L. Shaw. 1983. Nutritive value of antelope and desert bitterbrush, Stansbury cliffrose, and apache-plume. p. 173-185. In: Proc. Res. and Manage. of Bitterbrush and Cliffrose in Western North America. USDA Forest Serv. Gen. Tech. Rep. INT-152.

Young, V.A., and G.F. Payne. 1948. Utilization of key browse species in relation to proper grazing practices in cut-over western white pine lands in northern Idaho. J. Forest. 46:35-40.

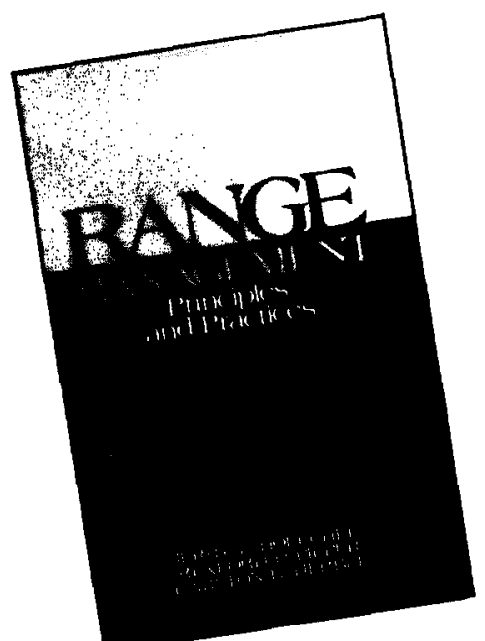

\section{New for 1989! \\ Covers all aspects of range management, including current and past research-}

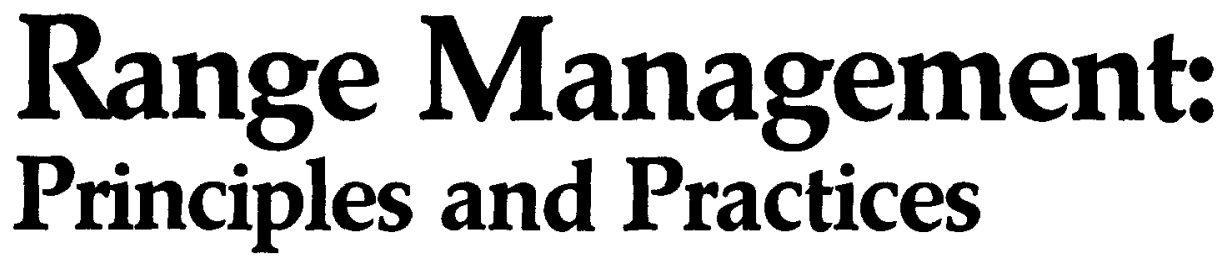

Jerry L. Holechek, Rex D. Pieper, and
Carlton H. Herbel, al o o New Mexico State University

This basic text provides full coverage of range management: history, policy on federal lands, plant ecology, grazing and wildlife management, range nutrition, problems in developing countries and range improvement.

\section{Practical in approach and targeted to the needs of today's range managers}

- Uses current and past publications and scientific reports as a foundation for concepts presented

- Presents economic and environmental consequences of range management practices

- Discusses grazing methods and supplemental feeding of range livestock

- Shows how to set stocking rates

- Includes 135 figures and 90 tables to illustrate various concepts

\section{Prentice Hall}

Book Distribution Center

Rt. 59 at Brookhill Drive West Niack, NY 10995-9901 (201) 767-5937

Price $\$ 48 /$ hard

Name

Address

Post/Zip Code 